\section{Kidney \\ Blood Pressure Research}

\title{
Vitamin D-Rich Diet in Mice Modulates Erythrocyte Survival
}

\author{
Elisabeth Lang ${ }^{a} \quad$ Kashif Jilania,b Rosi Bissinger ${ }^{a} \quad$ Rexhep Rexhepajc \\ Christine Zelenak $^{d} \quad$ Adrian Lupescu $^{\mathrm{a}} \quad$ Florian Lang $^{\mathrm{a}} \quad$ Syed M. Qadrie
}

aDepartment of Physiology, University of Tübingen, Germany; ${ }^{b}$ Department of Biochemistry, University of Agriculture, Faisalabad, Pakistan; Institute of Biochemistry and Molecular Biology, University of

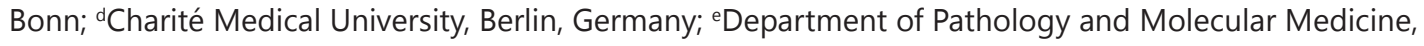
McMaster University, Hamilton, ON, Canada

\section{Key Words}

Vitamin D • Eryptosis $•$ Hyperosmotic shock $•$ Cell shrinkage $•$ Energy depletion

\begin{abstract}
Background/Aims: Epidemiological evidence suggests that vitamin $\mathrm{D}$ deficiency is associated with anemia. The potent metabolite $1,25(\mathrm{OH})_{2}$ vitamin $\mathrm{D}_{3}\left[1,25(\mathrm{OH})_{2} \mathrm{D}_{3}\right]$ activates various signaling cascades regulating a myriad of cellular functions including suicidal cell death or apoptosis. Suicidal death of erythrocytes or eryptosis is characterized by cell shrinkage and cell membrane scrambling leading to phosphatidylserine (PS) externalization. Stimulation of eryptosis may limit lifespan of circulating erythrocytes and thus cause anemia. In the present study, we explored the effect of a high vitamin D diet (10,000 I.U. vitamin D for 14 days) in mice on eryptosis. Methods: Plasma concentrations of erythropoietin were estimated using an immunoassay kit, blood count using an electronic hematology particle counter, relative reticulocyte numbers using Retic-COUNT ${ }^{\circledR}$ reagent, PS exposure at the cell surface from annexin $V$ binding, cell volume from forward scatter, and cytosolic $\mathrm{Ca}^{2+}\left(\left[\mathrm{Ca}^{2+}\right]_{\mathrm{i}}\right)$ from Fluo3fluorescence in FACS analysis. Results: Vitamin D treatment decreased mean corpuscular volume, reticulocyte count, and plasma erythropoietin levels. Vitamin D treatment slightly but significantly decreased forward scatter but did not significantly modify spontaneous PS exposure and $\left[\mathrm{Ca}^{2+}\right]_{i}$ of freshly drawn erythrocytes. Vitamin D treatment augmented the stimulation of PS exposure and cell shrinkage following exposure to hyperosmotic shock (addition of $550 \mathrm{mM}$ sucrose) or energy depletion (glucose removal) without significantly modifying $\left[\mathrm{Ca}^{2+}\right]_{\mathrm{i}}$. Conclusions: The present observations point to a subtle effect of exogenous vitamin $\mathrm{D}$ supplementation on erythrocyte survival.
\end{abstract}




\section{Kidney \\ Blood Pressure Research}

Kidney Blood Press Res 2015;40:403-412

\begin{tabular}{l|l}
\hline DOI: $10.1159 / 000368517$ & (C) 2015 S. Karger AG, Basel
\end{tabular}

Published online: July 27, 2015

www.karger.com/kbr

404

\section{Introduction}

The biologically active fat-soluble vitamin $\mathrm{D}$ is the precursor of the active hormone $1 \alpha, 25$-dihydroxyvitamin $\mathrm{D}\left[1,25(\mathrm{OH})_{2} \mathrm{D}_{3}\right]$ that plays a pivotal role in mineral homeostasis and skeletal health $[1,2]$. Metabolites of vitamin D further modify the physiology of nonskeletal tissues and, thus, regulate a wide array of biological functions $[3,4] .1,25(\mathrm{OH})_{2} \mathrm{D}_{3}$ activates various signaling cascades via the vitamin $D$ receptor which plays a decisive role in a myriad of cellular functions such as cell proliferation and differentiation, membrane transport, redox balance, adhesion, hemostasis and apoptosis [3-7]. Formation of $1,25(\mathrm{OH})_{2} \mathrm{D}_{3}$ is down-regulated by fibroblast growth factor 23 (FGF23) which, in turn, requires the membrane protein Klotho as a coreceptor [8-10]. As part of a negative feedback loop, both FGF23 and Klotho are stimulated by $1,25(\mathrm{OH})_{2} \mathrm{D}_{3}[10]$. Restriction of dietary vitamin D reverses accelerated aging in mice deficient in either FGF23 or Klotho [11-13]. Mounting epidemiological evidence suggests that vitamin D deficiency is associated with anemia [14-20]. Previous clinical observations have shown that vitamin D deficiency is linked to decreased haemoglobin, enhanced reticulocytosis and a reduced response to erythropoiesisstimulating agents $[20,21]$. Intriguingly, $1,25(\mathrm{OH})_{2} \mathrm{D}_{3}$ levels in bone marrow are a magnitude higher in comparison to their levels in plasma [22]. Animal experiments have revealed that FGF23 deficiency leads to hyperphosphatemia paralleled with increased levels of vitamin D and enhanced prenatal and postnatal erythropoiesis [23]. However, enhanced erythropoiesis in those mice was shown to be independent of increased $1,25(\mathrm{OH})_{2} \mathrm{D}_{3}$ levels [23].

Similar to nucleated cells, erythrocytes may undergo suicidal death or eryptosis, which is characterized by cell shrinkage and cell membrane scrambling [24, 25]. Triggers of eryptosis include activation of $\mathrm{Ca}^{2+}$-permeable cation channels with $\mathrm{Ca}^{2+}$ entry, activation of $\mathrm{Ca}^{2+}$-sensitive $\mathrm{K}^{+}$channels, exit of $\mathrm{KCl}$ with osmotically obliged water and, thus, cell shrinkage. Cytosolic $\mathrm{Ca}^{2+}$ further elicits scrambling of the erythrocyte membrane resulting in phosphatidylserine (PS) externalization [24-26]. The $\mathrm{Ca}^{2+}$ sensitivity of cell membrane scrambling is increased by ceramide. PS exposing erythrocytes are rapidly phagocytosed and, thus, cleared from circulating blood [24, 25]. Accordingly, accelerated eryptosis enhances the turnover of erythrocytes, which may lead to anemia, if the accelerated loss of erythrocytes is not compensated by a similar increase of erythrocyte formation, which is evident from reticulocytosis [27].

Both eryptosis and reticulocytosis were shown to be enhanced in Klotho-deficient mice and blunted in those mice by a vitamin D-depleted diet [28]. In conditions such as dehydration which is associated with decreased Klotho expression and enhanced $1,25(\mathrm{OH})_{2} \mathrm{D}_{3}$ levels, erythrocytes are particularly susceptible to eryptosis [29]. Furthermore, eryptosis could be enhanced by both, increase of extracellular phosphate concentration [30] and dietary phosphate depletion [31]. More recently, Klotho deficiency and increased vitamin D levels were shown to considerably impair erythropoiesis [32].

Whether excessive dietary intake of vitamin D influences erythrocyte lifespan, however, remained elusive. Thus, the present study explored whether a vitamin D-rich diet influences parameters of anemia and erythrocyte survival in mice.

\section{Materials and methods}

\section{Animals and treatment with vitamin D}

All animal experiments were conducted according to the German law for the welfare of animals and were approved by local authorities. Experiments were performed in female C57Bl6 mice at the age of 10 weeks. The mice had free access to water and control food (Sniff, Soest, Germany). To analyze the effects of vitamin D, mice were fed either a control diet (containing 500 I.U./kg vitamin D) or a vitamin D-rich diet (containing 10,000 I.U./kg vitamin D; Altromin, Lage, Germany) for 14 days [33]. 


\section{Kidney \\ Blood Pressure Research}

Kidney Blood Press Res 2015;40:403-412

\begin{tabular}{l|l}
\hline DOI: $10.1159 / 000368517$ & (c) 2015 S. Karger AG, Basel
\end{tabular}

Published online: July 27, 2015

www.karger.com/kbr

\section{Blood parameters}

For all experiments except for the blood count, heparin blood was retrieved from the mice. The plasma concentrations of erythropoietin were determined using an immunoassay kit according to the manufacturer's instructions (R\&D Systems, Wiesbaden, Germany). For the blood count, EDTA blood was analyzed using an electronic hematology particle counter (scil Vet abc, Weinheim, Germany). Murine erythrocytes were isolated by being washed two times with Ringer solution containing (in mM): $125 \mathrm{NaCl}, 5 \mathrm{KCl}, 1 \mathrm{MgSO}_{4}$, and $32 \mathrm{HEPES} / \mathrm{NaOH}$ (pH 7.4), 5 glucose, and $1 \mathrm{CaCl}_{2}$. Relative reticulocyte numbers were determined using the Retic-COUNT@ reagent (BD, Heidelberg, Germany) according to the manufacturer's instructions.

Incubations and solutions

For the in vitro experiments on suicidal death of erythrocytes, incubations were carried out at $37^{\circ} \mathrm{C}$ in Ringer solution at a hematocrit of $0.4 \%$ in a total volume of $500 \mu$ l. Where indicated, glucose was removed (energy depletion) or $550 \mathrm{mM}$ sucrose was added (hyperosmotic shock).

Phosphatidylserine exposure and forward scatter

After incubation, erythrocytes were washed once in Ringer solution containing $5 \mathrm{mM} \mathrm{CaCl}{ }_{2}$. The cells were then stained with annexin V-Fluos (Roche, Mannheim, Germany) at a 1:500 dilution. After 15 min, samples were measured by flow cytometric analysis (FACS-Calibur; BD). Cells were analyzed by forward scatter, and annexin $\mathrm{V}$ fluorescence intensity was measured in fluorescence channel FL-1 with an excitation wavelength of $488 \mathrm{~nm}$ and an emission wavelength of $530 \mathrm{~nm}$.

Measurement of intracellular $\mathrm{Ca}^{2+}$

After incubation, erythrocytes were washed in Ringer solution and then loaded with Fluo3/AM (Calbiochem) in Ringer solution containing $5 \mathrm{mM} \mathrm{CaCl}_{2}$ and $2 \mu \mathrm{M}$ Fluo3/AM. The cells were incubated at $37^{\circ} \mathrm{C}$ for $20 \mathrm{~min}$ and washed twice in Ringer solution containing $5 \mathrm{mM} \mathrm{CaCl}$. The Fluo3/AM-loaded erythrocytes were resuspended in $50 \mu$ Ringer. Then, $\mathrm{Ca}^{2+}$-dependent fluorescence intensity was measured in fluorescence channel FL-1 in FACS analysis.

Statistics

Data are expressed as arithmetic mean \pm SEM, and statistical analysis was made by paired or unpaired $t$ test or ANOVA, as appropriate. Values of $P<0.05$ were considered statistically significant.

\section{Results}

Blood analysis of the mice revealed significantly reduced MCV in vitamin D-treated mice as compared to control mice (Fig. 1A). The hemoglobin concentration tended to be higher in vitamin D-treated mice, an effect, however, not reaching statistical significance (Fig. 1A). On the contrary, however, the percentage of reticulocytes and plasma erythropoietin levels were significantly lower in vitamin D-treated mice than in control mice (Fig. 1B and 1C).

Examination of erythrocyte survival by quantifying PS exposure using fluorescent annexin $\mathrm{V}$ binding revealed that the percentage of annexin $\mathrm{V}$ positive erythrocytes tended to be lower in freshly drawn erythrocytes from vitamin D-treated mice as compared to erythrocytes drawn from control mice (Fig. 2A and 2B). After $24 \mathrm{~h}$ incubation in Ringer solution, annexin $\mathrm{V}$ binding again tended to be lower in erythrocytes from vitamin D-treated mice than in erythrocytes from control mice (Fig. 2C). Changes in erythrocyte cell volume were studied using forward scatter in FACS analysis. Forward scatter was significantly smaller in freshly drawn erythrocytes from vitamin D-treated mice than in freshly drawn erythrocytes from control mice (Fig. 2D and 2E). Following incubation for $24 \mathrm{~h}$ in Ringer solution forward scatter was again significantly smaller in erythrocytes from vitamin D-treated mice than in erythrocytes from control mice (Fig. 2F).

Enhanced cytosolic $\mathrm{Ca}^{2+}$ activity mediates erythrocyte cell membrane scrambling and shrinkage via $\mathrm{Ca}^{2+}$-activated $\mathrm{K}^{+}$channels. To this end, cytosolic $\mathrm{Ca}^{2+}$ activity was examined 


\section{Kidney Blood Pressure Research}

Fig. 1. Effect of vitamin D treatment on blood parameters, reticulocyte count and plasma erythropoietin. A. Means \pm SEM $(n=10)$ of mean corpuscular volume (MCV), mean corpuscular hemoglobin $(\mathrm{MCH})$, mean corpuscular hemoglobin concentration (MCHC), red cell distribution width (RDW), hemoglobin concentration (HGB) and hematocrit (HCT) of mice were fed for 14 days either a control diet of 500 I.U./kg vitamin D (white bars), or a vitamin D-rich diet of 10,000 I.U./kg vitamin D (black bars). * significant $(\mathrm{p}<0.05)$ from Control. B,C. Means \pm SEM $(n=10)$ of Kidney Blood Press Res 2015;40:403-412

\begin{tabular}{l|l}
\hline DOI: $10.1159 / 000368517$ & C 2015 S. Karger AG, Basel
\end{tabular}

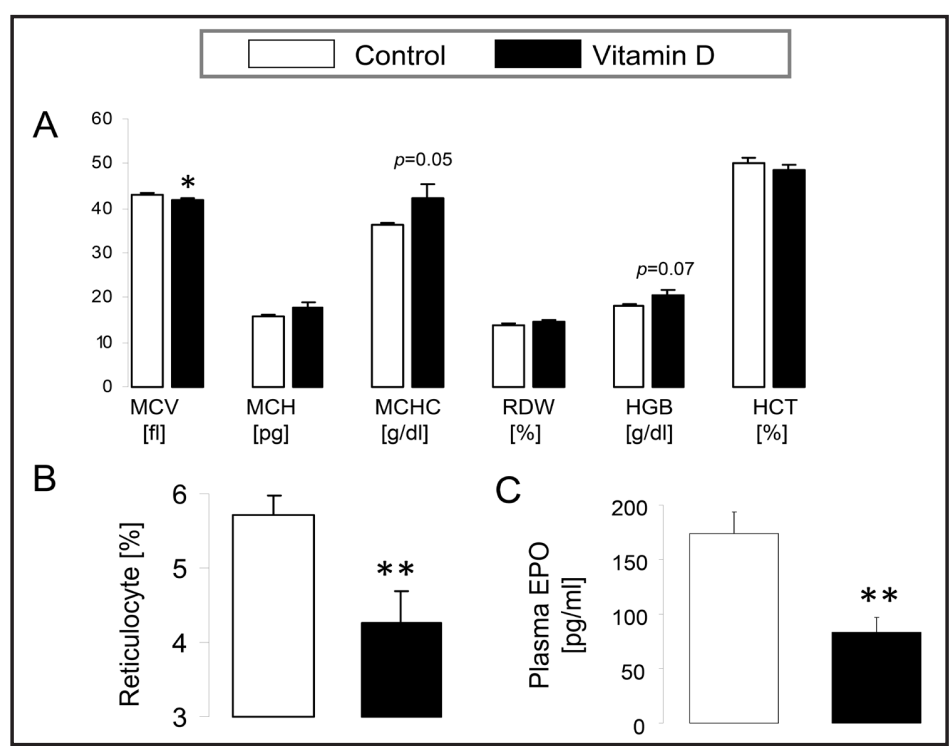
the percentage of reticulocytes $(\mathbf{B}, \mathrm{n}=10)$ and plasma erythropoietin levels $(\mathbf{C}, \mathrm{n}=5)$ in control (white bars) and vitamin D-treated (black bars) mice. ${ }^{* *}$ significant $(\mathrm{p}<0.01)$ from control.

Fig. 2. Effect of vitamin D treatment on erythrocyte phosphatidylserine externalization and cell shrinkage. (A) Histogram of annexin V-binding in Control (red shadow) and vitamin D-treated mice (black line). B,C. Means \pm SEM ( $n=5-10)$ of PS-exposing erythrocytes determined in fresh drawn (B) erythrocytes and in erythrocytes incubated for $24 \mathrm{~h}$ (C) drawn from control (white bars) and vitamin D-treated (black bars) mice. D. Histogram of forward scatter in Control (red shadow) and vitamin D-treated mice (black line). E,F. Means \pm

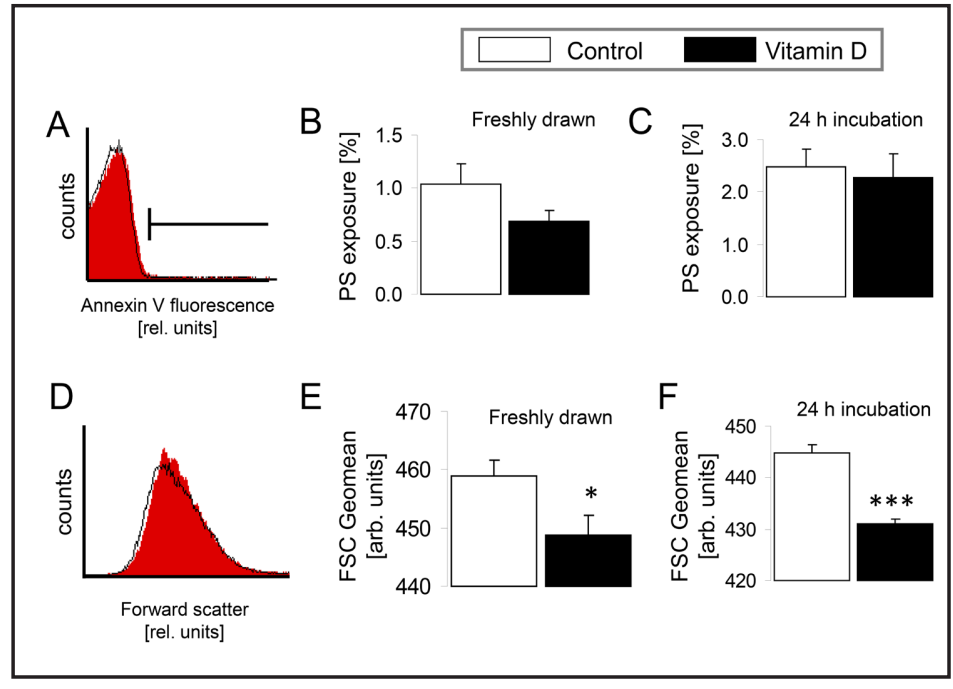

SEM ( $\mathrm{n}=5-10)$ of forward scatter geomean determined in fresh drawn (E) erythrocytes and in erythrocytes incubated for $24 \mathrm{~h}$ (F) drawn from control (white bars) and vitamin D-treated (black bars) mice. *, *** $(\mathrm{p}<0.05, \mathrm{p}<0.001)$ different from Control.

using Fluo3 fluorescence in FACS analysis. As a result, fluo3 fluorescence in freshly drawn erythrocytes was similar without (15.3 \pm 0.3 a.u., $\mathrm{n}=10)$ and with $(15.4 \pm 0.3$ a.u., $\mathrm{n}=10)$ prior vitamin D treatment. Following 24 hours incubation, fluo3 fluorescence tended to be lower in erythrocytes from vitamin $D$ treated animals (15.5 \pm 0.9 a.u., $n=5)$ than in erythrocytes from untreated animals (17.3 \pm 0.5 a.u., $n=5)$, a difference, however, not reaching statistical significance.

Further experiments explored whether vitamin D treatment influenced the susceptibility of erythrocytes to known stimulators of eryptosis. In order to explore the impact of vitamin D treatment on susceptibility to eryptosis triggered by hyperosmotic shock, erythrocytes were exposed to hyperosmotic Ringer solution. As illustrated in Fig. 3A and 3B, osmotic shock 


\section{Kidney Blood Pressure Research}

Fig. 3. Effect of vitamin D treatment on erythrocyte phosphatidylserine externalization and cell shrinkage following hyperosmotic shock. A. Histogram of annexin V-binding in Control (red shadow) and vitamin D-treated mice (black line) exposed to $\mathrm{Hy}$ perosmotic (+550 $\mathrm{mM}$ sucrose) Ringer and B. means \pm SEM $(n=10)$ of PS-exposure determined in erythrocytes incubated for $1 \mathrm{~h}$ in Isosmotic or Hyperosmotic (+550 mM sucrose) Ringer. ${ }^{* * *}$ significant $(\mathrm{p}<0.001)$ from Isosmotic. \# significant $(\mathrm{p}<0.01)$ from Control. C. Histogram of Kidney Blood Press Res 2015;40:403-412

\begin{tabular}{l|l}
\hline DOI: $10.1159 / 000368517$ & C 2015 S. Karger AG, Basel
\end{tabular}

Lang/Jilani/Bissinger/Rexhepaj/Zelenak/Lupescu/Lang/Qadri: Vitamin D-Sensitive Eryptosis

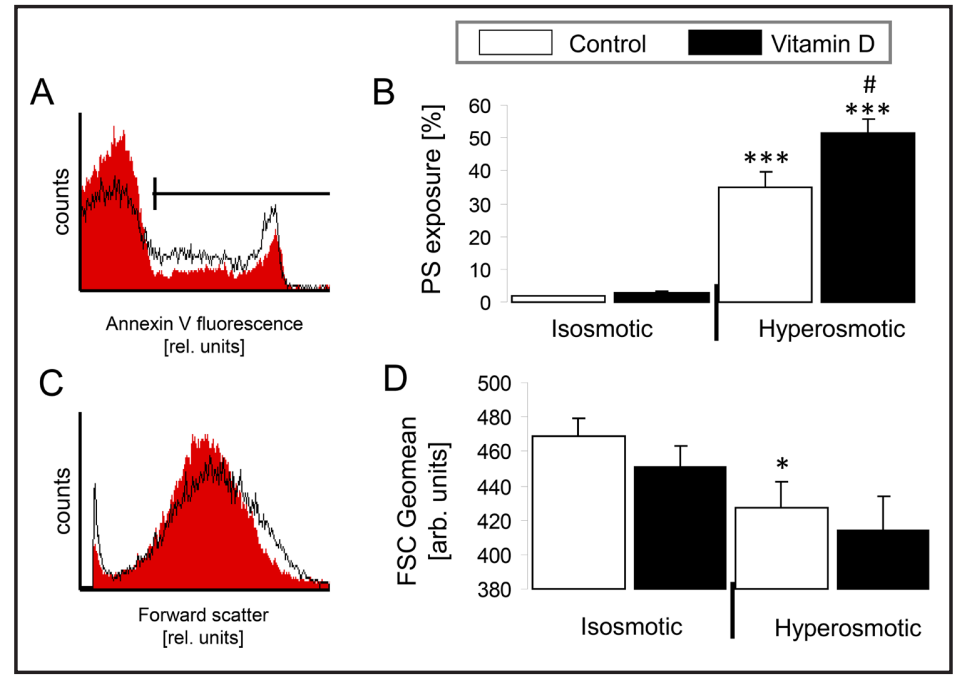

forward scatter geomean in Control (red shadow) and vitamin D-treated mice (black line) exposed to Hyperosmotic (+550 mM sucrose) Ringer. D. Means \pm SEM $(n=10)$ of forward scatter geomean determined in erythrocytes incubated for $1 \mathrm{~h}$ in Isosmotic or Hyperosmotic (+550 mM sucrose) Ringer. * significant $(\mathrm{p}<0.001)$ from Isosmotic.

Fig. 4. Effect of vitamin D treatment on erythrocyte cytosolic $\mathrm{Ca}^{2+}$ activity following hyperosmotic shock. A. Histogram of Fluo3 fluorescence in Control (red shadow) and vitamin D-treated mice (black line) exposed to Hyperosmotic (+550 $\mathrm{mM}$ sucrose) Ringer and $\mathbf{B}$. Means \pm SEM $(n=10)$ of Fluo3 geomean determined in eryth-

rocytes incubated for $1 \mathrm{~h}$ in Isosmotic (left bars) or Hyperosmotic (+550 mM sucrose, right bars) Ringer. *** significant $(\mathrm{p}<0.001)$ from Isosmotic.

enhanced PS exposure, an effect significantly more pronounced in erythrocytes from vitamin D-treated mice than in erythrocytes drawn from control mice. Osmotic shock decreased the forward scatter to a similar extent in erythrocytes from vitamin D-treated and control mice (Fig. 3C and 3D).

A further series of experiments explored whether vitamin D treatment similarly augmented the effect of hyperosmotic shock on cytosolic $\mathrm{Ca}^{2+}$ activity. As illustrated in Fig. 4, hyperosmotic shock significantly increased Fluo3 fluorescence to similar values in erythrocytes from control and vitamin D-treated mice (Fig. 4).

As eryptosis is further stimulated by energy depletion, an additional series of experiments explored the effect of glucose removal from the extracellular medium. As a result, incubation of erythrocytes for $12 \mathrm{~h}$ in glucose-free Ringer solution increased PS exposure, an effect significantly more pronounced in erythrocytes from vitamin D-treated mice than in erythrocytes from control mice (Fig. 5). 


\section{Kidney \\ Blood Pressure Research}

Fig. 5. Effect of vitamin D treatment on erythrocyte phosphatidylserine externalization following energy depletion. A. Histogram of annexin V-binding in Control (red shadow) and vitamin D-treated mice (black line) exposed to glucose-depleted Ringer and B. Means \pm SEM $(n=5)$ of PS-exposure determined in erythrocytes incubated for $12 \mathrm{~h}$ in Ringer solution Kidney Blood Press Res 2015;40:403-412

\begin{tabular}{l|l}
\hline DOI: $10.1159 / 000368517$ & C 2015 S. Karger AG, Basel \\
www.kargercom/kbr
\end{tabular}

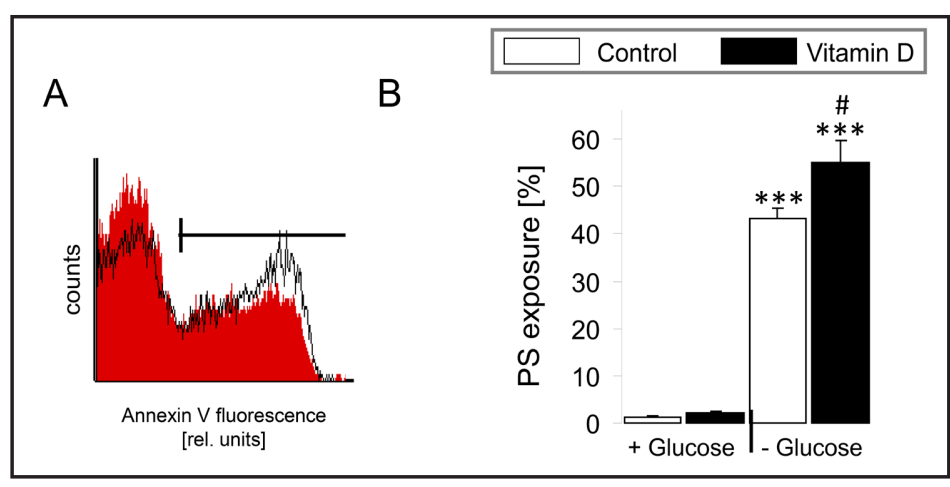

$\left(+\right.$ Glucose) or glucose-depleted Ringer solution (-Glucose). ${ }^{* * *}$ significant $(\mathrm{p}<0.001)$ from energy repletion. \# significant $(\mathrm{p}<0.01)$ from Control.

\section{Discussion}

According to the present observations, systemic administration of vitamin D suppresses the reticulocyte count, an effect paralleled by and possibly due to decreased plasma erythropoietin levels. Volume of freshly drawn erythrocytes was slightly but significantly smaller in Vitamin D treated animals than in control animals. Most importantly, erythrocytes from vitamin D treated animals were more susceptible to eryptosis than erythrocytes from control animals to eryptosis following ex vivo cell stress such as hyperosmotic shock and energy depletion.

Eryptosis is enhanced in Klotho-deficient mice [28], which suffer from excessive formation of $1,25(\mathrm{OH})_{2}$ vitamin $\mathrm{D}_{3}$ [8-10]. The enhanced eryptosis in Klotho-deficient mice could be reversed by reduction in dietary vitamin D intake [28]. According to the present study, vitamin D treatment alone did not cause anemia and did not stimulate eryptosis of freshly drawn erythrocytes but sensitized the erythrocytes to the proeryptotic effect of hyperosmotic shock and energy depletion.

In a variety of nucleated cells $1,25(\mathrm{OH})_{2} \mathrm{D}_{3}$ has been shown to foster $\mathrm{Ca}^{2+}$ entry [6, 34-36]. In erythrocytes the eryptosis following hyperosmotic shock is not paralleled by appreciable increase of cytosolic $\mathrm{Ca}^{2+}$ and vitamin $\mathrm{D}$ treatment is presumably not effective by stimulating $\mathrm{Ca}^{2+}$-entry. Hyperosmotic shock elicits ceramide formation in eryptotic erythrocytes, which may trigger eryptosis even at constant cytosolic $\mathrm{Ca}^{2+}[37]$. Vitamin D analogs have previously been shown to potentiate ceramide-dependent apoptosis of tumor cells [38]. Osmotic shock is further followed by phosphorylation of erythrocyte p38 MAPK [24], which participates in the signaling of $1,25(\mathrm{OH})_{2} \mathrm{D}_{3}$-induced nucleated cell death $[39,40] .1,25(\mathrm{OH})_{2} \mathrm{D}_{3}$ further affects nitric oxide formation [41] and protein kinase $C$ activity [42], which both participate in the regulation of eryptosis $[43,44]$. Other signaling molecules participating in the signaling of eryptosis include AMPK [45], CK1 $\alpha$ [46], Janus kinase 3 [24] and PAK2 [47]. Whether those kinases participate in the effects of vitamin D on erythrocytes, remains to be shown.

Eryptosis is enhanced by erythrocyte age [48], a wide variety of anemia-causing xenobiotics and endogeneous substances [29, 30, 49-68] as well as several clinical disorders, such as iron deficiency [27], hepatic failure [69], chronic kidney disease [70], sepsis [71], malignancy [72] and Wilson's disease [73]. Eryptosis may further influence erythrocytes stored for transfusion [74]. It is likely that excessive vitamin D may compound the susceptibility to the eryptotic effect of eryptosis-inducing xenobiotics, endogeneous mediators and clinical disorders.

Phosphatidylserine-exposing erythrocytes adhere to the vascular wall [75], and stimulate blood clotting [76]. Thus, excessive eryptosis may compromise microcirculation. Along those lines, enhanced eryptosis has been suggested to participate in the vascular injury of metabolic syndrome [77]. 


\section{Kidney \\ Blood Pressure Research}

\section{Conclusion}

Taken together, our data suggest a subtle effect of exogenous vitamin D supplementation on erythrocyte survival in vivo and in response to cell stress ex vivo.

\section{Disclosure Statement}

The authors of this manuscript state that they do not have any conflict of interests and nothing to disclose.

\section{Acknowledgements}

The authors thank Tanja Loch for the meticulous preparation of the manuscript. This study was supported by the Deutsche Forschungsgemeinschaft, Nr. La 315/4-3 and La 315/6-1 and the Bundesministerium für Bildung, Wissenschaft, Forschung und Technologie (Center for Interdisciplinary Clinical Research).

\section{References}

1 Norman PE, Powell JT: Vitamin D and cardiovascular disease. Circ Res 2014;114:379-393.

2 Zittermann A: Vitamin D and cardiovascular disease. Anticancer Res 2014;34:4641-4648.

3 Bouillon R, Carmeliet G, Verlinden L, van EE, Verstuyf A, Luderer HF, Lieben L, Mathieu C, Demay M: Vitamin D and human health: lessons from vitamin D receptor null mice. Endocr Rev 2008;29:726-776.

4 DeLuca HF: Overview of general physiologic features and functions of vitamin D. Am J Clin Nutr 2004;80:1689S-1696S.

5 Dong X, Craig T, Xing N, Bachman LA, Paya CV, Weih F, McKean DJ, Kumar R, Griffin MD: Direct transcriptional regulation of RelB by 1alpha,25-dihydroxyvitamin D3 and its analogs: physiologic and therapeutic implications for dendritic cell function. J Biol Chem 2003;278:49378-49385.

6 Shumilina E, Xuan NT, Matzner N, Bhandaru M, Zemtsova IM, Lang F: Regulation of calcium signaling in dendritic cells by 1,25-dihydroxyvitamin D3. FASEB J 2010;24:1989-1996.

7 Geldmeyer-Hilt K, Heine G, Hartmann B, Baumgrass R, Radbruch A, Worm M: 1,25-dihydroxyvitamin D3 impairs NF-kappaB activation in human naive B cells. Biochem Biophys Res Commun 2011;407:699-702.

8 Kuro-o M: Overview of the FGF23-Klotho axis. Pediatr Nephrol 2010;25:583-590.

9 Feger M, Fajol A, Lebedeva A, Meissner A, Michael D, Voelkl J, Alesutan I, Schleicher E, Reichetzeder C, Hocher B, Qadri SM, Lang F: Effect of carbon monoxide donor CORM-2 on vitamin D3 metabolism. Kidney Blood Press Res 2013;37:496-505.

10 Fakhri H, Pathare G, Fajol A, Zhang B, Bock T, Kandolf R, Schleicher E, Biber J, Foller M, Lang UE, Lang F: Regulation of mineral metabolism by lithium. Pflugers Arch 2014;466:467-475.

11 Nabeshima Y: Toward a better understanding of Klotho. Sci Aging Knowledge Environ 2006;2006:e11.

12 Shimada T, Kakitani M, Yamazaki Y, Hasegawa H, Takeuchi Y, Fujita T, Fukumoto S, Tomizuka K, Yamashita T: Targeted ablation of Fgf23 demonstrates an essential physiological role of FGF23 in phosphate and vitamin D metabolism. J Clin Invest 2004;113:561-568.

13 Tsujikawa H, Kurotaki Y, Fujimori T, Fukuda K, Nabeshima Y: Klotho, a gene related to a syndrome resembling human premature aging, functions in a negative regulatory circuit of vitamin $D$ endocrine system. Mol Endocrinol 2003;17:2393-2403.

14 Ozsoylu S, Aytekin MN: Vitamin D deficiency and anemia. Ann Hematol 2011;90:737.

15 Sim JJ, Lac PT, Liu IL, Meguerditchian SO, Kumar VA, Kujubu DA, Rasgon SA: Vitamin D deficiency and anemia: a cross-sectional study. Ann Hematol 2010;89:447-452.

16 Coutard A, Garlantezec R, Estivin S, Andro M, Gentric A: Association of vitamin D deficiency and anemia in a hospitalized geriatric population: denutrition as a confounding factor. Ann Hematol 2013;92:615-619. 


\section{Kidney \\ Blood Pressure Research}

Kidney Blood Press Res 2015;40:403-412

\begin{tabular}{l|l}
\hline DOI: 10.1159/000368517 & (c) 2015 S. Karger AG, Basel
\end{tabular}

Published online: July 27, 2015

www.karger.com/kbr

17 Wykes C, Arasaretnam A, O'Driscoll S, Farnham L, Moniz C, Rees DC: Vitamin D deficiency and its correction in children with sickle cell anaemia. Ann Hematol 2014;93:2051-2056.

18 Lee JA, Hwang JS, Hwang IT, Kim DH, Seo JH, Lim JS: Low vitamin d levels are associated with both iron deficiency and anemia in children and adolescents. Pediatr Hematol Oncol 2015;32:99-108.

19 Yoo EH, Cho HJ: Prevalence of 25-hydroxyvitamin d deficiency in korean patients with anemia. J Clin Lab Anal 2015;29:129-134.

20 Icardi A, Paoletti E, De NL, Mazzaferro S, Russo R, Cozzolino M: Renal anaemia and EPO hyporesponsiveness associated with vitamin D deficiency: the potential role of inflammation. Nephrol Dial Transplant 2013;28:1672-1679.

21 Lucisano S, Di ME, Montalto G, Cernaro V, Buemi M, Santoro D: Vitamin D and anemia. J Ren Nutr 2014;24:61-62.

22 Blazsek I, Farabos C, Quittet P, Labat ML, Bringuier AF, Triana BK, Machover D, Reynes M, Misset JL: Bone marrow stromal cell defects and 1 alpha,25-dihydroxyvitamin D3 deficiency underlying human myeloid leukemias. Cancer Detect Prev 1996;20:31-42.

23 Coe LM, Madathil SV, Casu C, Lanske B, Rivella S, Sitara D: FGF-23 is a negative regulator of prenatal and postnatal erythropoiesis. J Biol Chem 2014;289:9795-9810.

24 Lang E, Qadri SM, Lang F: Killing me softly - suicidal erythrocyte death. Int J Biochem Cell Biol 2012;44:1236-1243.

25 Lang F, Qadri SM: Mechanisms and significance of eryptosis, the suicidal death of erythrocytes. Blood Purif 2012;33:125-130.

26 Berg CP, Engels IH, Rothbart A, Lauber K, Renz A, Schlosser SF, Schulze-Osthoff K, Wesselborg S: Human mature red blood cells express caspase- 3 and caspase-8, but are devoid of mitochondrial regulators of apoptosis. Cell Death Differ 2001;8:1197-1206.

27 Kempe DS, Lang PA, Duranton C, Akel A, Lang KS, Huber SM, Wieder T, Lang F: Enhanced programmed cell death of iron-deficient erythrocytes. FASEB J 2006;20:368-370.

28 Kempe DS, Ackermann TF, Fischer SS, Koka S, Boini KM, Mahmud H, Foller M, Rosenblatt KP, Kuro O, Lang F: Accelerated suicidal erythrocyte death in Klotho-deficient mice. Pflugers Arch 2009;458:503-512.

29 Abed M, Feger M, Alzoubi K, Pakladok T, Frauenfeld L, Geiger C, Towhid ST, Lang F: Sensitization of erythrocytes to suicidal erythrocyte death following water deprivation. Kidney Blood Press Res 2013;37:567-578.

30 Voelkl J, Alzoubi K, Mamar AK, Ahmed MS, Abed M, Lang F: Stimulation of suicidal erythrocyte death by increased extracellular phosphate concentrations. Kidney Blood Press Res 2013;38:42-51.

31 Birka C, Lang PA, Kempe DS, Hoefling L, Tanneur V, Duranton C, Nammi S, Henke G, Myssina S, Krikov M, Huber SM, Wieder T, Lang F: Enhanced susceptibility to erythrocyte "apoptosis" following phosphate depletion. Pflugers Arch 2004;448:471-477.

32 Vadakke MS, Coe LM, Casu C, Sitara D: Klotho deficiency disrupts hematopoietic stem cell development and erythropoiesis. Am J Pathol 2014;184:827-841.

33 Rexhepaj R, Alesutan I, Gu S, Pelzl L, Eichenmuller M, Pathare G, Foller M, Kuhl D, Lang F: SGK1-dependent stimulation of intestinal SGLT1 activity by vitamin D. Pflugers Arch 2011;462:489-494.

34 Christakos S, Dhawan P, Benn B, Porta A, Hediger M, Oh GT, Jeung EB, Zhong Y, Ajibade D, Dhawan K, Joshi S: Vitamin D: molecular mechanism of action. Ann NY Acad Sci 2007;1116:340-348.

35 Ishizawa M, Matsunawa M, Adachi R, Uno S, Ikeda K, Masuno H, Shimizu M, Iwasaki K, Yamada S, Makishima M: Lithocholic acid derivatives act as selective vitamin D receptor modulators without inducing hypercalcemia. J Lipid Res 2008;49:763-772.

36 Renkema KY, Alexander RT, Bindels RJ, Hoenderop JG: Calcium and phosphate homeostasis: concerted interplay of new regulators. Ann Med 2008;40:82-91.

37 Lang KS, Myssina S, Brand V, Sandu C, Lang PA, Berchtold S, Huber SM, Lang F, Wieder T: Involvement of ceramide in hyperosmotic shock-induced death of erythrocytes. Cell Death Differ 2004;11:231-243.

38 Pirianov G, Danielsson C, Carlberg C, James SY, Colston KW: Potentiation by vitamin D analogs of TNFalpha and ceramide-induced apoptosis in MCF-7 cells is associated with activation of cytosolic phospholipase A2. Cell Death Differ 1999;6:890-901.

39 Brosseau CM, Pirianov G, Colston KW: Involvement of stress activated protein kinases (JNK and p38) in 1,25 dihydroxyvitamin D3-induced breast cell death. Steroids 2010;75:1082-1088. 


\section{Kidney \\ Blood Pressure Research}

Kidney Blood Press Res 2015;40:403-412

\begin{tabular}{l|l}
\hline DOI: 10.1159/000368517 & (c) 2015 S. Karger AG, Basel
\end{tabular}

Published online: July 27, 2015

www.karger.com/kbr

40 Rosso A, Pansera M, Zamoner A, Zanatta L, Bouraima-Lelong H, Carreau S, Silva FR: 1alpha,25(OH)2Vitamin D3 stimulates rapid plasma membrane calcium influx via MAPK activation in immature rat Sertoli cells. Biochimie 2012;94:146-154.

41 Uberti F, Lattuada D, Morsanuto V, Nava U, Bolis G, Vacca G, Squarzanti DF, Cisari C, Molinari C: Vitamin D protects human endothelial cells from oxidative stress through the autophagic and survival pathways. J Clin Endocrinol Metab 2014;99:1367-1374.

42 Buitrago C, Costabel M, Boland R: PKC and PTPalpha participate in Src activation by 1alpha,25OH2 vitamin D3 in C2C12 skeletal muscle cells. Mol Cell Endocrinol 2011;339:81-89.

43 Klarl BA, Lang PA, Kempe DS, Niemoeller OM, Akel A, Sobiesiak M, Eisele K, Podolski M, Huber SM, Wieder T, Lang F: Protein kinase $\mathrm{C}$ mediates erythrocyte "programmed cell death" following glucose depletion. Am J Physiol Cell Physiol 2006;290:C244-C253.

44 Nicolay JP, Liebig G, Niemoeller OM, Koka S, Ghashghaeinia M, Wieder T, Haendeler J, Busse R, Lang F: Inhibition of suicidal erythrocyte death by nitric oxide. Pflugers Arch 2008;456:293-305.

45 Foller M, Sopjani M, Koka S, Gu S, Mahmud H, Wang K, Floride E, Schleicher E, Schulz E, Munzel T, Lang F: Regulation of erythrocyte survival by AMP-activated protein kinase. FASEB J 2009;23:1072-1080.

46 Zelenak C, Eberhard M, Jilani K, Qadri SM, Macek B, Lang F: Protein kinase CK1alpha regulates erythrocyte survival. Cell Physiol Biochem 2012;29:171-180.

47 Zelenak C, Foller M, Velic A, Krug K, Qadri SM, Viollet B, Lang F, Macek B: Proteome analysis of erythrocytes lacking AMP-activated protein kinase reveals a role of PAK2 kinase in eryptosis. J Proteome Res 2011;10:1690-1697.

48 Ghashghaeinia M, Cluitmans JC, Akel A, Dreischer P, Toulany M, Koberle M, Skabytska Y, Saki M, Biedermann T, Duszenko M, Lang F, Wieder T, Bosman GJ: The impact of erythrocyte age on eryptosis. Br J Haematol 2012;157:606-614.

49 Ahmed MS, Langer H, Abed M, Voelkl J, Lang F: The uremic toxin acrolein promotes suicidal erythrocyte death. Kidney Blood Press Res 2013;37:158-167.

50 Alzoubi K, Calabro S, Bissinger R, Abed M, Faggio C, Lang F: Stimulation of suicidal erythrocyte death by artesunate. Cell Physiol Biochem 2014;34:2232-2244.

51 Bissinger R, Fischer S, Jilani K, Lang F: Stimulation of erythrocyte death by phloretin. Cell Physiol Biochem 2014;34:2256-2265.

52 Bissinger R, Lupescu A, Zelenak C, Jilani K, Lang F: Stimulation of eryptosis by cryptotanshinone. Cell Physiol Biochem 2014;34:432-442.

53 Gatidis S, Foller M, Lang F: Hemin-induced suicidal erythrocyte death. Ann Hematol 2009;88:721-726.

54 Jilani K, Qadri SM, Lang F: Geldanamycin-induced phosphatidylserine translocation in the erythrocyte membrane. Cell Physiol Biochem 2013;32:1600-1609.

55 Lupescu A, Bissinger R, Herrmann T, Oswald G, Jilani K, Lang F: Induction of suicidal erythrocyte death by novobiocin. Cell Physiol Biochem 2014;33:670-680.

56 Lupescu A, Jilani K, Zbidah M, Lang F: Patulin-induced suicidal erythrocyte death. Cell Physiol Biochem 2013;32:291-299.

57 Malik A, Bissinger R, Calabro S, Faggio C, Jilani K, Lang F: Aristolochic acid induced suicidal erythrocyte death. Kidney Blood Press Res 2014;39:408-419.

58 Abed M, Herrmann T, Alzoubi K, Pakladok T, Lang F: Tannic acid induced suicidal erythrocyte death. Cell Physiol Biochem 2013;32:1106-1116.

59 Arnold M, Bissinger R, Lang F: Mitoxantrone-induced suicidal erythrocyte death. Cell Physiol Biochem 2014;34:1756-1767.

60 Bissinger R, Modicano P, Frauenfeld L, Lang E, Jacobi J, Faggio C, Lang F: Estramustine-induced suicidal erythrocyte death. Cell Physiol Biochem 2013;32:1426-1436.

61 Ghashghaeinia M, Cluitmans JC, Toulany M, Saki M, Koberle M, Lang E, Dreischer P, Biedermann T, Duszenko M, Lang F, Bosman GJ, Wieder T: Age sensitivity of NFkappaB abundance and programmed cell death in erythrocytes induced by NFkappaB inhibitors. Cell Physiol Biochem 2013;32:801-813.

62 Jacobi J, Lang E, Bissinger R, Frauenfeld L, Modicano P, Faggio C, Abed M, Lang F: Stimulation of erythrocyte cell membrane scrambling by mitotane. Cell Physiol Biochem 2014;33:1516-1526.

63 Lupescu A, Bissinger R, Warsi J, Jilani K, Lang F: Stimulation of erythrocyte cell membrane scrambling by gedunin. Cell Physiol Biochem 2014;33:1838-1848. 


\section{Kidney \\ Blood Pressure Research}

Kidney Blood Press Res 2015;40:403-412

\begin{tabular}{l|l}
\hline DOI: 10.1159/000368517 & (c) 2015 S. Karger AG, Basel
\end{tabular}

Published online: July 27, 2015

www.karger.com/kbr

64 Tesoriere L, Attanzio A, Allegra M, Cilla A, Gentile C, Livrea MA: Oxysterol mixture in hypercholesterolemiarelevant proportion causes oxidative stress-dependent eryptosis. Cell Physiol Biochem 2014;34:10751089.

65 Zhang R, Xiang Y, Ran Q, Deng X, Xiao Y, Xiang L, Li Z: Involvement of calcium, reactive oxygen species, and ATP in hexavalent chromium-induced damage in red blood cells. Cell Physiol Biochem 2014;34:1780-1791.

66 Arnold M, Lang E, Modicano P, Bissinger R, Faggio C, Abed M, Lang F: Effect of nitazoxanide on erythrocytes. Basic Clin Pharmacol Toxicol 2014;114:421-426.

67 Dermaku-Sopjani M, Abazi S, Faggio C, Kolgeci J, Sopjani M: AMPK-sensitive cellular transport. J Biochem 2014;155:147-158.

68 Faggio C, Alzoubi K, Calabro S, Lang F: Stimulation of suicidal erythrocyte death by PRIMA-1. Cell Physiol Biochem 2015;35:529-540.

69 Lang E, Gatidis S, Freise NF, Bock H, Kubitz R, Lauermann C, Orth HM, Klindt C, Schuier M, Keitel V, Reich M, Liu G, Schmidt S, Xu HC, Qadri SM, Herebian D, Pandyra AA, Mayatepek E, Gulbins E, Lang F, Haussinger D, Lang KS, Foller M, Lang PA: Conjugated bilirubin triggers anemia by inducing erythrocyte death. Hepatology 2015;61:275-284.

70 Abed M, Artunc F, Alzoubi K, Honisch S, Baumann D, Foller M, Lang F: Suicidal erythrocyte death in endstage renal disease. J Mol Med (Berl) 2014;92:871-879.

71 Kempe DS, Akel A, Lang PA, Hermle T, Biswas R, Muresanu J, Friedrich B, Dreischer P, Wolz C, Schumacher U, Peschel A, Gotz F, Doring G, Wieder T, Gulbins E, Lang F: Suicidal erythrocyte death in sepsis. J Mol Med (Berl) 2007;85:273-281.

72 Qadri SM, Mahmud H, Lang E, Gu S, Bobbala D, Zelenak C, Jilani K, Siegfried A, Foller M, Lang F: Enhanced suicidal erythrocyte death in mice carrying a loss-of-function mutation of the adenomatous polyposis coli gene. J Cell Mol Med 2012;16:1085-1093.

73 Lang PA, Schenck M, Nicolay JP, Becker JU, Kempe DS, Lupescu A, Koka S, Eisele K, Klarl BA, Rubben H, Schmid KW, Mann K, Hildenbrand S, Hefter H, Huber SM, Wieder T, Erhardt A, Haussinger D, Gulbins E, Lang F: Liver cell death and anemia in Wilson disease involve acid sphingomyelinase and ceramide. Nat Med 2007;13:164-170.

74 Kriebardis AG, Antonelou MH, Stamoulis KE, Economou-Petersen E, Margaritis LH, Papassideri IS: Progressive oxidation of cytoskeletal proteins and accumulation of denatured hemoglobin in stored red cells. J Cell Mol Med 2007;11:148-155.

75 Borst O, Abed M, Alesutan I, Towhid ST, Qadri SM, Foller M, Gawaz M, Lang F: Dynamic adhesion of eryptotic erythrocytes to endothelial cells via CXCL16/SR-PSOX. Am J Physiol Cell Physiol 2012;302:C644-C651.

76 Chung SM, Bae ON, Lim KM, Noh JY, Lee MY, Jung YS, Chung JH: Lysophosphatidic acid induces thrombogenic activity through phosphatidylserine exposure and procoagulant microvesicle generation in human erythrocytes. Arterioscler Thromb Vasc Biol 2007;27:414-421.

77 Zappulla D: Environmental stress, erythrocyte dysfunctions, inflammation, and the metabolic syndrome: adaptations to CO2 increases? J Cardiometab Syndr 2008;3:30-34. 